The End of Burnout 



\section{The End of Burnout}

WHY WORK DRAINS US AND HOW TO

BUILD BETTER LIVES

\section{Jonathan Malesic}

呾 UNIVERSITY OF CALIFORNIA PRESS 
University of California Press

Oakland, California

(C) 2022 by Jonathan Malesic

Library of Congress Cataloging-in-Publication Data

Names: Malesic, Jonathan, 1975- author.

Title: The end of burnout : why work drains us and how to build better lives / Jonathan Malesic.

Description: Oakland, California : University of California Press, [2022] | Includes bibliographical references and index.

Identifiers: LC C N 2021012142 (print) | LC C N 2021012143 (ebook) | IS BN 9780520344075 (cloth) | IS BN 9780520975347 (ebook)

Subjects: LC SH: Burn out (Psychology)

Classification: LC C BF 481 .M 2752022 (print) | LC C BF 481 (ebook) | D DC $158.7 / 23-$ dc23

LC record available at https://lccn.loc.gov/2021012142

LC ebook record available at https://lccn.loc.gov/2021012143

Manufactured in the United States of America

$\begin{array}{llllllllll}31 & 30 & 29 & 28 & 27 & 26 & 25 & 24 & 23 & 22\end{array}$

$\begin{array}{llllllllll}10 & 9 & 8 & 7 & 6 & 5 & 4 & 3 & 2 & 1\end{array}$ 
"You don't have to like it. That's why it's called work." GEORGE MALESIC (1933-2018) 
